\title{
Pichia hawaiiensis sp. nov., occurring in decaying bark of Charpentiera trees in the Hawaiian archipelago
}

\author{
Herman J. Phaff, ${ }^{1}$ William T. Starmer ${ }^{2}$ and Cletus P. Kurtzman ${ }^{3}$ \\ Author for correspondence: Herman J. Phaff. Tel: +1 530752 1465. Fax: + 15307524759. \\ e-mail: hjphaff@ucdavis.edu
}

1 Department of Food Science and Technology, University of California, Davis, CA 95616, USA

2 Department of Biology, Syracuse University, Syracuse, NY 13244, USA

3 Microbial Properties Research Unit, National Center for Agricultural Utilization Research, Agricultural Research Service, US Department of Agriculture, Peoria, IL 61604, USA

\begin{abstract}
A description is given for Pichia hawaiiensis sp. nov., a nitrate-utilizing member of the genus Pichia E. C. Hansen emend. Kurtzman. Seven strains of the new species were isolated during the years 1972, 1973 and 1978 from rotting bark of the Hawaiian tree genera Charpentiera, Pisonia and Cheirodendron. P. hawaiiensis is heterothallic but appears to occur in nature mainly in the diploid state. Asci are deliquescent and produce up to four hatshaped spores per ascus. Phylogenetic analysis of the 600 nucleotide D1/D2 domain of the 26S rDNA showed that $P$. hawaiiensis is most closely related to Pichia populi and Williopsis californica (syn. Hansenula californica). The type strain of $P$. hawaiiensis, isolated on the island of Hawaii from the rotting bark of Charpentiera sp. containing insect larvae, is strain UCD-FST 72-181' ( = ATCC MYA-137 $^{\top}={\text { CBS } 8760^{\top}}^{\top}=$ NRRL Y-27270').
\end{abstract}

Keywords: Pichia hawaiiensis sp. nov., phylogenetic analysis, large-subunit rDNA analysis

\section{INTRODUCTION}

During explorations (in 1972, 1973 and 1978) of the yeast biota associated with native Hawaiian plants, seven phenotypically similar strains of a species representative of the yeast genus Pichia E. C. Hansen emend. Kurtzman were recovered from rotting bark samples of several endemic tree species on the islands of Hawaii and Kauai in the Hawaiian archipelago. Attempts to identify these isolates by using standard yeast identification methods that depend on diagnostic responses to physiological tests (Kurtzman, 1984, 1998; Barnett et al., 1990) failed to give satisfactory matches with known species. Because of the common variability of certain physiological tests (Kurtzman \& Fell, 1998) or tests controlled by single nuclear genes (such as hydrolases), confirmation of the novelty of the Hawaiian isolates was sought from divergence in the variable D1/D2 domain of the large-subunit (26S) rDNA. Kurtzman \& Robnett $(1995,1997,1998)$ have demonstrated that the extent of divergence in this domain appears sufficient to resolve all species of ascomycetous yeasts that differ in terms of nucleotide

Abbreviation: LSU, large subunit.

The GenBank accession number for the 26S rDNA D1/D2 sequence of Pichia hawaiiensis is AF153675. substitutions by $1 \%$ or more. Comparison of the D1/D2 sequence from a representative strain of the Hawaiian isolates with a database of D1/D2 sequences from all currently utilized ascomycetous yeasts (Kurtzman \& Robnett, 1997, 1998) revealed that these isolates represent a new species and also provided an estimate of phylogenetic placement.

We propose to name the new species Pichia hawaiiensis because of the geographic area of origin, which includes two of the Hawaiian islands, ranging from the northwest island of Kauai to the island of Hawaii at the eastern end of the archipelago.

\section{METHODS}

Strain isolation. Samples of moist, rotting tree bark were collected in sterile plastic containers from Charpentiera (Amaranthaceae) sp., Cheirodendron (Araliaceae) sp. and Pisonia sp. (Nyctaginaceae) in Volcanoes National Park on the island of Hawaii, and at Honopu on the island of Kauai. Samples were streaked on acidified (to $\mathrm{pH} 3 \cdot 8$ with $1 \mathrm{M} \mathrm{HCl}$ ) yeast extract/malt extract agar (YM; Difco) and stored at approximately $25^{\circ} \mathrm{C}$. Pure cultures were obtained by restreaking on YM agar. Morphological and physiological characteristics of the isolates were determined using methods currently used in yeast taxonomy (Yarrow, 1998). Among the many strains isolated from the above sources during three separate collection trips, seven strains were represen- 
Table 1. Strain numbers, host plants, origins and ploidy of Pichia hawaiiensis isolates

\begin{tabular}{|c|c|c|}
\hline Strain* & Host plant and location & Ploidy \\
\hline UCD $72-181^{\mathrm{T}}$ & Rotting bark of Charpentiera sp., Island of Hawaii & Diploid \\
\hline UCD 72-170 & Rotting bark of Charpentiera sp., Island of Hawaii & Diploid \\
\hline UCD 73-508.1 & Rotting bark of Charpentiera sp., Island of Hawaii & Diploid \\
\hline S 78-341.1 & Rotting bark of Pisonia sp., Island of Hawaii & Diploid \\
\hline S 78-345.1 & Rotting bark of Pisonia sp., Island of Hawaii & Diploid \\
\hline S $78-346.1$ & Rotting bark of Cheirodendron sp., Island of Hawaii & Diploid \\
\hline S 78-689.1 & Rotting bark of Charpentiera sp., Island of Kauai & Diploid \\
\hline UCD 72-181.1 & Single-spore isolate from UCD $72-181^{\mathrm{T}}$ & Haploid $\mathrm{h}^{+}$ \\
\hline UCD $72-181.2$ & Single-spore isolate from UCD $72-181^{\mathrm{T}}$ & Haploid $\mathrm{h}^{-}$ \\
\hline UCD $72-181.3$ & Single-spore isolate from UCD $72-181^{\mathrm{T}}$ & Haploid $\mathrm{h}^{+}$ \\
\hline UCD 72-181.4 & Single-spore isolate from UCD $72-181^{\mathrm{T}}$ & Haploid $\mathrm{h}^{-}$ \\
\hline
\end{tabular}

* UCD (= UCD-FST), Culture Collection of the Department of Food Science and Technology, University of California, Davis, CA, USA; S prefix, assigned by W. T. Starmer. The four singleascospore isolates came from the same ascus.

tative of $P$. hawaiiensis (Table 1). Single ascospores produced on dilute $(1: 4) \mathrm{V}-8$ agar were isolated from individual fourspored asci with the aid of a micromanipulator (Fowell, 1969).

DNA isolation, PCR, rDNA sequencing and sequence analysis. Methods for nuclear DNA isolation, amplification of the 600-nucleotide 26S rDNA domain D1/D2 by PCR and sequencing with the ABI Taq DyeDeoxy Terminator Cycle sequencing kit and the ABI model 377 automated DNA sequencer (Applied Biosystems) were as described previously (Kurtzman \& Robnett, 1997).

Sequence data were visually aligned with QEDIT 2.15 (SemWare). Phylogenetic relationships were calculated with a Power Macintosh 8500/120 using the maximum-parsimony program of PAUP* 4.0 (Swofford, 1993; test version distributed by Sinauer Associates) with the heuristic search option and random addition of sequences. Relationships were further analysed using the neighbour-joining program of PAUP* 4.0 with the Jukes-Cantor distance measure.

Schizosaccharomyces pombe was designated outgroup in all analyses. Support for the nodes of the phylogenetic tree were estimated from bootstrap analysis (1000 replications). The GenBank accession numbers for reference species have been reported by Kurtzman \& Robnett (1998).

\section{RESULTS AND DISCUSSION}

Phylogenetic placement of $P$. hawaiiensis was determined from analysis of 26S rDNA domain D1/D2 sequences (approx. 600 nucleotides) from all currently recognized ascomycetous yeast species, as reported in the study by Kurtzman \& Robnett (1998). This analysis demonstrated that $P$. hawaiiensis is a unique species that is closely related to Pichia populi (56 nucleotide differences) and Williopsis californica (63 nucleotide differences) as shown in Fig. 1. Weak basal branch support is evident from the domain D1/D2 analysis presented in Fig. 1, and complete 18S sequence analyses are often similarly weak (Kurtzman $\&$ Robnett, 1998). In view of the uncertainty con- cerning the phylogenetic circumscription of Pichia, Williopsis and related genera, the new ascosporic species described here is placed in Pichia as currently defined from phenotypic characteristics (Kurtzman, 1998).

$P$. hawaiiensis can be differentiated phenotypically from $P$. populi by its lack of growth on D-mannitol, Dglucitol and D-gluconate as sole carbon sources or on cadaverine as the sole source of nitrogen. It differs from $W$. californica by its lack of growth on Dmannitol, D-gluconate and citrate as sole carbon sources.

\section{Latin diagnosis of Pichia hawaiiensis Phaff, Starmer \& Kurtzman sp. nov.}

In YM (Difco) liquido post dies 5 ad $25^{\circ} \mathrm{C}$, cellulae ovoideae, 2-4 $\times 5-6.5 \mu \mathrm{m}$, singulae, binae aut catenis brevis; sedimentum pallidum, annulus tenuis; pellicula nulla. Cultura in agaro malti post dies 21 ad $25^{\circ} \mathrm{C}$ cremea vel ravida, butyrosa, plana, nitida, margo glabrum vel serrulatum. In agaro farinae Zea mays post dies 10 pseudomycelium nullum vel rudimentarium. Cultura heterothallica. Asci formantur ex cellulae diploideae, habentus 2-4 sporos pileiformae; asci rumpunter post dies 4-10. Fermentatio glucosi tarda. Glucosum, cellobiosum, D-xylosum, L-rhamnosum (exigue, tarda), ethanolum, glycerolum, salicinum, methyl $\beta$-D-glucosidum, acidum lacticum, acidum succinicum assimilantur at non galactosum, L-sorbosum, maltosum, saccharosum, trehalosum, lactosum, melibiosum, raffinosum, melezitosum, inulinum, amylum solubile, L-arabinosum, D-arabinosum, D-ribosum, erythritolum, ribitolum, galactitolum, D-mannitolum, D-glucitolum, methyl- $\alpha$-D-glucosidum, glucono- $\delta$ lactonum, 2-ketogluconatum, 5-ketogluconatum, acidum citricum, meso-inositolum, D-gluconatum, methanolum, D-glucosaminum, $N$-acetyl-D-glucosaminum, nec hexadecanum. Kalium nitricum, Natrium nitrosum, lysinum, 


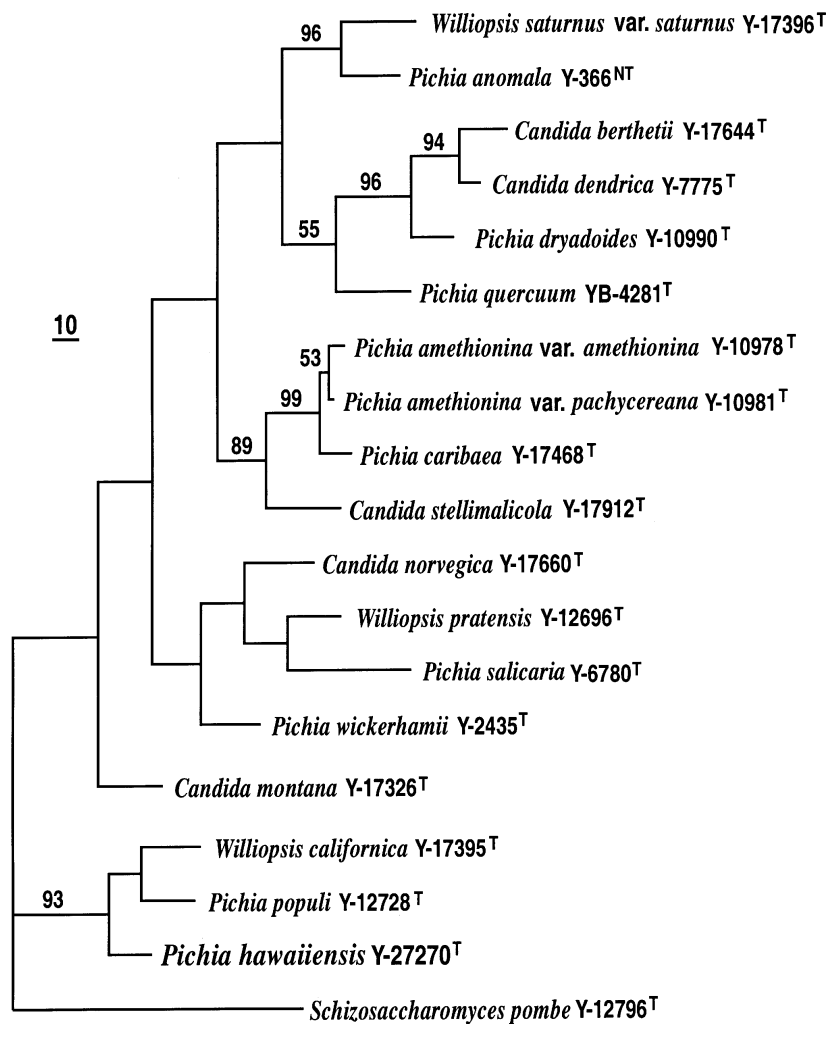

Fig. 1. Phylogenetic tree showing placement of Pichia hawaiiensis among near relatives as represented by one of six most parsimonious trees derived from maximum-parsimony analysis of $26 \mathrm{~S}$ rDNA domain D1/D2. Branch lengths are proportional to nucleotide differences, as indicated by the bar. Numbers given at nodes are the percentage of frequencies with which a given branch appeared in 1000 bootstrap replicates. Frequencies under $50 \%$ are not given. Tree length, 838; consistency index, 0.521; retention index, 0.509; rescaled consistency index, 0.266; homoplasy index, 0.479; parsimonyinformative characteristics, 185. Schizosaccharomyces pombe served as the outgroup species for the analysis.

ethyl aminum assimilantur at non cadaverinum. Ad crescentiam vitaminae additae necessariae sunt. Crescere potest in $25^{\circ} \mathrm{C}$ at non in $30^{\circ} \mathrm{C}$. Habitatio ad corticem putrescens arborum Hawaiiensis. Typus: stirps UCD-FST $72-181^{\mathrm{T}}$ ex cortex Charpentiera $\mathrm{sp}$. isolata est. In collectione zymotica Centraalbureau voor Schimmelcultures, Delphi Batavorum sub no. CBS $8760^{\mathrm{T}}$ deposita est.

\section{Description of Pichia hawaiiensis Phaff, Starmer \& Kurtzman sp. nov.}

Pichia hawaiiensis (ha.wai.i.ensis' L. adj., referring to the geographic origin of the new species).

In YM (Difco) liquid medium after $5 \mathrm{~d}$ at $25^{\circ} \mathrm{C}$, the cells are ovoid, $2-4 \times 5-6.5 \mu \mathrm{m}$, single, in pairs or in small clusters. After 1 week, a moderate amount of sediment and a thin ring develop; a pellicle is lacking. After $21 \mathrm{~d}$ at $25^{\circ} \mathrm{C}$, streak cultures on malt agar are cream to greyish in colour, butyrous to pasty, smooth,
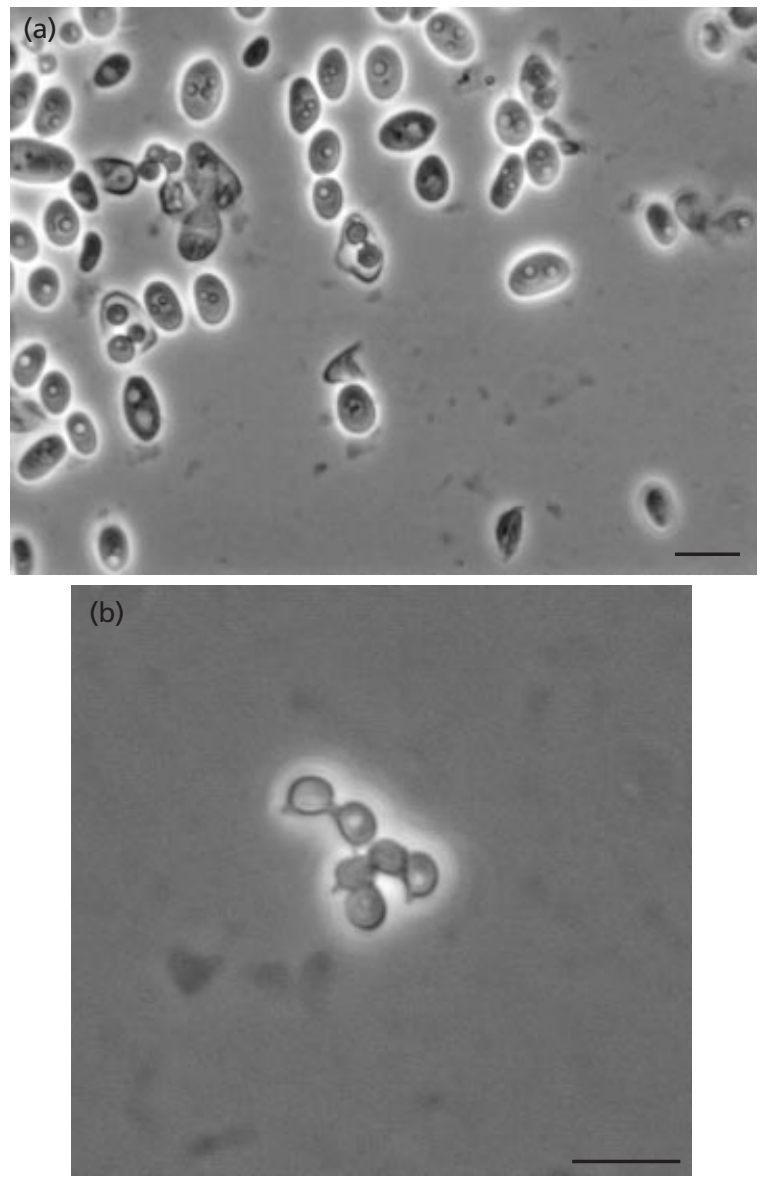

Fig. 2. $P$. hawaiiensis on $V-8(1: 4)$ agar sporulation medium at $22-25^{\circ} \mathrm{C}$. (a) Vegetative cells and asci in the process of rupturing after $7 \mathrm{~d}$; bar, $6.5 \mu \mathrm{m}$. (b) A cluster of liberated hatshaped ascospores with protruding 'brims' after $10 \mathrm{~d}$; bar, $3 \mu \mathrm{m}$.

flat to slightly raised, glossy and have borders that are entire to finely crenate. On cornmeal agar after $10 \mathrm{~d}$, pseudomycelium is rudimentary or absent. On dilute (1:4) filtered V-8-juice agar at $\mathrm{pH} 6 \cdot 0$, four hat-shaped spores are formed which are rapidly liberated from the asci upon maturity. The spores are small, measuring approximately $1-1.5 \mu \mathrm{m}$, and have a tendency to agglutinate in clumps (Fig. 2). The species is heterothallic. Mating-type segregation results in two $h+$ and two $\mathrm{h}-$ spores from a four-spored ascus (Table 1). When cultures of $h+$ and $h-$ cells are mixed on V-8 sporulation medium, very few zygotes are seen after one or two days. Apparently, spores do not develop directly in zygotes, but instead they produce diploid buds which proliferate and produce spores after 6-10 d (Fig. 2a). Only glucose is fermented (latently and slowly). The following carbon sources are assimilated: glucose, cellobiose, D-xylose, L-rhamnose (latent, weak), ethanol, glycerol, salicin (weak), methyl $\beta$-Dglucoside, DL-lactic acid and succinic acid. The following are not assimilated: D-galactose, L-sorbose, maltose, sucrose, trehalose, lactose, melibiose, raffi- 
nose, melezitose, inulin, soluble starch, L-arabinose, D-arabinose, D-ribose, erythritol, ribitol, galactitol, D-mannitol, D-glucitol, methyl- $\alpha$-D-glucoside, glucono- $\delta$-lactone, D-gluconate, 2-keto-gluconate, 5keto-gluconate, citric acid, meso-inositol, methanol, D-glucosamine, $N$-acetyl-D-glucosamine and hexadecane. $\mathrm{KNO}_{3}, \mathrm{NaNO}_{2}$, ethylamine and L-lysine are utilized as sole sources of nitrogen but cadaverine is not utilized. Does not grow in vitamin-free medium. Does not grow in the presence of $100 \mu \mathrm{g}$ cycloheximide $\mathrm{ml}^{-1}$. Shows weak growth on YM agar containing $5 \% \mathrm{NaCl}$ and no growth at $10 \% \mathrm{NaCl}$. Does not grow in the presence of $50 \%(\mathrm{w} / \mathrm{w})$ glucose. Grows at $25^{\circ} \mathrm{C}$; no growth at $30{ }^{\circ} \mathrm{C}$. Does not hydrolyse gelatin; casein is hydrolysed latently and weakly. Does not produce urease or lipolytic activity. The habitat is moist, rotting bark of Charpentiera sp. and several other native Hawaiian tree species (Table 1). The type strain, UCD-FST $72-181^{\mathrm{T}}$, has been deposited in the American Type Culture Collection as strain ATCC MYA-137 ${ }^{\mathrm{T}}$, in the Centraalbureau voor Schimmelcultures (Delft, The Netherlands) as strain CBS $8760^{\mathrm{T}}$ and in the ARS Culture Collection (National Center for Agricultural Utilization Research, Peoria, IL, USA) as NRRL Y $-27270^{\mathrm{T}}$. Strains of $P$. hawaiiensis isolated during three expeditions to Hawaii and their sources are given in Table 1. On the basis of the rearing records of Montgomery (1975), it is assumed that the vector of transmission of $P$. hawaiiensis is one or several picturewinged Drosophila species that use(s) the three host plants indicated in Table 1 as larval breeding sites or feeding sites on the Hawaiian islands.

\section{ACKNOWLEDGEMENTS}

Thanks are given to Christie J. Robnett for determining the domain D1/D2 26S rDNA sequences and to Kyria BoundyMills for preparing the photomicrographs.

\section{REFERENCES}

Barnett, J. A., Payne, R. W. \& Yarrow, D. (1990). Yeasts: Characteristics and Identification, 2nd edn. Cambridge: Cambridge University Press.

Fowell, R. R. (1969). Sporulation and hybridization of yeasts. In The Yeasts. Vol. I. Biology of Yeasts, pp. 303-383. Edited by A. H. Rose \& J. S. Harrison. New York: Academic Press.

Kurtzman, C. P. (1984). Pichia Hansen. In The Yeasts, a Taxonomic Study, 3rd edn, pp. 295-378. Edited by N. J. W. Kreger-van Rij. Amsterdam: Elsevier.

Kurtzman, C. P. (1998). Pichia E. C. Hansen emend. Kurtzman. In The Yeasts, a Taxonomic Study, 4th edn, pp. 273-352. Edited by C. P. Kurtzman \& J. W. Fell. Amsterdam: Elsevier.

Kurtzman, C. P. \& Fell, J. W. (1998). Summary of species characteristics. In The Yeasts, a Taxonomic Study, 4th edn, pp. 915-947. Edited by C. P. Kurtzman \& J. W. Fell. Amsterdam: Elsevier.

Kurtzman, C. P. \& Robnett, C. J. (1995). Molecular relationships among hyphal ascomycetous yeasts and yeastlike taxa. Can $J$ Bot 73, S824-S830.

Kurtzman, C. P. \& Robnett, C. J. (1997). Identification of clinically important ascomycetous yeasts based on nucleotide divergence in the $5^{\prime}$ end of the large-subunit (26S) ribosomal DNA gene. $J$ Clin Microbiol 35, 1216-1223.

Kurtzman, C. P. \& Robnett, C. J. (1998). Identification and phylogeny of ascomycetous yeasts from analysis of nuclear large subunit (26S) ribosomal DNA partial sequences. Antonie Leeuwenhoek 73, 331-371.

Montgomery, S. L. (1975). Comparative breeding site ecology and the adaptive radiation of picture-winged Drosophila (Diptera: Drosophilidae) in Hawaii. Proc Hawaii Entomol Soc 22, 65-103.

Swofford, D. L. (1993). PAUP: phylogenetic analysis using parsimony, version 3.1.1. Illinois Natural History Survey, Champaign, IL, USA.

Yarrow, D. (1998). Methods for the isolation, maintenance and identification of yeasts. In The Yeasts, a Taxonomic Study, 4th edn, pp. 77-100. Edited by C. P. Kurtzman \& J. W. Fell. Amsterdam: Elsevier. 